\title{
Adam Mestyan
}

\section{ARABIC THEATER IN EARLY KHEDIVIAL CULTURE, 1868-72: JAMES SANUA REVISITED}

\begin{abstract}
This article revisits the official culture of the early khedivate through a microhistory of the first modern Egyptian theater in Arabic. Based on archival research, it aims at a recalibration of recent scholarship by showing khedivial culture as a complex framework of competing patriotisms. It analyzes the discourse about theater in the Arabic press, including the journalist Muhammad Unsi's call for performances in Arabic in 1870. It shows that the realization of this idea was the theater group led by James Sanua between 1871 and 1872, which also performed 'Abd al-Fattah al-Misri's tragedy. But the troupe was not an expression of subversive nationalism, as has been claimed by scholars. My historical reconstruction and my analysis of the content of Sanua's comedies show loyalism toward the Khedive Ismail. Yet his form of contemporary satire was incompatible with elite cultural patriotism, which employed historicization as its dominant technique. This revision throws new light on a crucial moment of social change in the history of modern Egypt, when the ruler was expected to preside over the plural cultural bodies of the nation.
\end{abstract}

In 2001, a heated debate occurred in the Egyptian press. The theater historian Sayyid 'Ali Isma'il claimed that everything we know about what had been generally considered the first modern Egyptian theater in Arabic, led by James Sanua (1839-1912), derives from Sanua's own writings, and that the pioneer of Egyptian theater was not Sanua but Muhammad 'Uthman Jalal (1829-98), a translator of French poetry and plays. Isma'il's main opponent was Muhammad Yusuf Najm, the Lebanese doyen of Arab theater history, who affirmed the existence of Sanua's theater and rebutted Isma 'il's claims with the argument that pioneering in theater means staging, not translating, plays. ${ }^{1}$ Isma ${ }^{\mathrm{i}} \mathrm{l}$ now grants the pioneering role to the Beiruti migrant translator, impresario, and journalist Salim Naqqash (1856-84), and since Najm's death in 2009 has continued his attempts to delete Sanua from Arab theater history. ${ }^{2}$

So why is James Sanua important? His mother was an Egyptian Jew and his father an Italian Jew who migrated from Livorno to Egypt. Sanua grew up in Cairo and studied for a few years in Livorno. After his return, he taught language in schools and to elite families in Cairo in the 1860s. Sanua wrote poetry and plays, and, as I prove in this article, he did establish a short-lived theater troupe in 1871. In the spring of 1878 he

Adam Mestyan is a Junior Fellow at the Society of Fellows, Harvard University, Cambridge, Mass.; e-mail: mestyan@fas.harvard.edu

(C) Cambridge University Press 2014 0020-7438/14 \$15.00 
started to print a satiric and subversive Arabic journal, Abu Naddara (also spelled Abu Nazzara). He was exiled and continued the journal in Paris from mid-summer of the same year. After 1882 he wrote against the British occupation of Egypt. He confessed himself an Egyptian patriot and a believer in the unity of religions, though he used Islam as a uniting anti-khedivial and anti-British political tool. Because of the "exaggerated sense of self-importance" in his writings, his journalism is a challenging case of antiBritish propaganda in the name of the Egyptian nation. ${ }^{3}$ Sanua's first two significant biographers fell, to some extent, into this trap. In the 1950s and 1960s, press historian Ibrahim 'Abduh described him as a "Muslim Jew" (al-yahūdīal-muslim) ${ }^{4}$ while political scientist Irene L. Gendzier invoked him as a "reminder that past generations witnessed a more amicable and constructive relationship between those two peoples." 5 Today, Sanua continues to be portrayed as a somewhat atypical "Arab Jew." conflict between Palestinians, 20th-century Arab states, and Israel as one between "two peoples" (Arabs and Jews or Muslims and Jews), and the projection of this ethnicized conflict back to the 19th century, have shaped the perceptions of Sanua.

Scholarly interpretations have generally claimed that Sanua from his youth "sought to arouse resentment against the tyrannous rule of the Khedivial administration,"7 that the idea of Arabic theater "never occurred to an Egyptian before him," " that he "clarified his commitment to Egyptian nationalism, expressing himself first in the medium of theater," that "he became the creator of the Egyptian national theatre," 10 and that his plays "contain subtle nationalistic themes." 'Abd al-Hamid Ghunaym called Sanua a "revolutionary actor who transformed his jesting theater into a mirror, to reflect the life of the Egyptian peasant and worker."12 His career has been seen as the consistent development of a subversive ethos, expressed first in theater, then in journalism. ${ }^{13}$

At the same time, as Sanua himself admitted, and Gendzier recognizes, the theater was a royally sponsored project. ${ }^{14}$ Anwar Luqa, Matti Moosa, Najwa Ibrahim 'Anus, Mustafa Badawi, and Philip Sadgrove in particular have already attempted to verify Sanua's narrative, mostly by analyzing his posthumously printed plays or unearthing contemporary sources. ${ }^{15}$ Luqa emphasizes that his theater has been seen through the lenses of his later journalism. ${ }^{16}$ Moosa remarks that "it is evident that he too enjoyed the Khedive's favour." 17 The historian Alexander Schölch calls Sanua "a sort of court jester." 18 There is an evident contradiction between the image of a revolutionary hero and that of a playwright sponsored by the ruler.

Building upon these critiques, this article revisits cultural life in Cairo between 1868 and 1872 in order to verify the theatrical activity of Sanua and to provide a new interpretation. I argue that his troupe cannot be regarded as an expression of subversive nationalism. This isolated and aborted experiment, operating for around one year during 1871-72, can only be understood in its loyalist relation to the ruling elite, not in opposition to it. It failed because Sanua's colloquial comedies did not contain historical themes and history was central to the dominant technique of 19th-century elite opera and drama. At the same time, a student of al-Azhar, Muhammad 'Abd al-Fattah, composed a historicized tragedy that was performed by Sanua's troupe and would have fit in with the official representation of the state. Furthermore, other Egyptian intellectuals were interested in theater in Arabic earlier or at the same time, in particular the journalist Muhammad Unsi, who emphasized the importance of the Arab historical legacy. Joining the recent interest 
in theater as a source for the modern history of the Middle East, ${ }^{19} \mathrm{I}$ demonstrate the ways in which individuals from below attempted to connect to the ruler as representatives of new political communities using diverse techniques to produce novel works in Arabic. These expressions of cultural patriotisms in Egypt within the frames of khedivial culture challenge the dualistic simplification of nationalist and subversive versus colonial and monarchical narratives.

\section{KHEDIVIAL CULTURE}

Ziad Fahmy divides the Egyptian cultural landscape into popular and elite cultures in order to unearth the use of Arabic vernacular(s) in the formation of national identity. ${ }^{20}$ In addition to this sociolinguistic approach, it is fruitful to experiment with the distinction between official or state and nonofficial culture in general, because in this way the political framework in which both "elite" and "popular" were constructed becomes more evident. Since these categories are often associated with value judgments, it is important to understand them as historically evolving and context dependent.

In 19th-century Egypt, the almost independent Ottoman governor was identical to the "state." His and his family members' sponsorship of entertainment and art made these "state" matters. Four spheres of such sponsorship may be distinguished: harem entertainment, court culture, urban entertainment for the broader population, and in the later part of the century public institutions such as theaters. One might add to this list the sponsorship of individuals by notables, including female members of the court or of rich households. There is not much evidence that Mehmet Ali Pasha (r. 1805-48) ${ }^{21}$ had any interest in sponsoring literary works written in learned Arabic (al-fushha) or entertainment conducted in the mostly spoken Arabic vernacular(s) (al-'ámmiyya), ${ }^{22}$ apart from translations of technical manuals for military purposes. Harem and court entertainment was generally in Ottoman Turkish. ${ }^{23}$ Though Abbas Pasha (r. 1849-54) could converse in Arabic with ease, there is a lack of information on whether he enjoyed entertainment in Arabic. ${ }^{24}$ Nonetheless, works in written Arabic were presented to the rulers. These range from the Azhari shaykh Ahmad al-Rajabi's panegyric supporting Mehmet Ali in $1821,{ }^{25}$ to praises for the victorious Ibrahim in Ottoman Syria in the $1830 \mathrm{~s},{ }^{26}$ to the $q a s \bar{a}^{\text {’id }}$ offered to the visiting Sait Pasha (r. 1854-63) in 1859 in Beirut. ${ }^{27}$ Sait Pasha started to invest in entertainment he thought would please Egyptian soldiers. In the 1850s he commissioned Rifa ${ }^{c}$ a Rafi ${ }^{c}$ al-Tahtawi to continue the composition of Arabic poems (wataniyyāt) ${ }^{28}$ that the soldiers could sing while marching. He also distributed the biography of Napoleon in Arabic to them. ${ }^{29}$ However, poems composed by an educated shaykh differed from the entertainment of the Egyptian rank and file. ${ }^{30}$

Ismail Pasha (r. 1863-79) invested in public institutions of art in Cairo (Comédie, Circus, Opera House, Hippodrome, and a small theater in the Azbakiyya Garden) and sponsored their staff and the visiting Italian and French troupes. He also sponsored works in Arabic, including poems and songs, individual artists (for instance, 'Abduh al-Hamuli, an Ottomanized Egyptian singer), newspapers (Wadi al-Nil in Cairo, alJawa'ib in Istanbul, and Hadiqat al-Akhbar in Beirut), and the spread of classical texts through the establishment of the Khedivial Library and printing houses. The patronage of Arabic works was very modest compared to the funds channeled into Italian and French entertainment, but the works all served as aesthetic means to enhance the 
splendor of his reign. This resulted in what Nadia Al-Bagdadi describes as "vorgestellte Öffentlichkeit" (an imagined/re-presented public sphere), ${ }^{31}$ because in addition to the new public institutions, Ismail's censorship aimed at a full monopoly over the public sphere in Egypt.

I use the term "khedivial culture" to describe state culture in Egypt between 1867 and 1914. In this period Egypt was legally a khedivate, a unique Ottoman form of statehood. Ismail Pasha and his successors officially used the title "khedive" from 1867 as a new Ottoman rank (Mehmet Ali, Abbas, and Sait had already used it). The khedivate was maintained from 1882 to 1914 by the British occupiers, when the colonial state became distinguished from the ruler's own sphere of influence. The khedivate was intimately connected to the new aesthetics. The term "khedivial culture" includes all cultural experiments, whether they were what we now conceptualize as of elite or popular inception, in Italian, French, Arabic, Ottoman Turkish, or Greek, that were approved, ordered, or produced by the khedives and the men and women associated with them in this period.

\section{THE INFRASTRUCTURE OF KHEDIVIAL CULTURE AND MODERN}

\section{ARABIC THEATER}

Khedivial culture as the public assemblage of state-related works (buildings, texts, performances, images) can be translated into the terminology of power as an "operatic state" in Egypt. This expression, coined by Ruth Bereson (though Clifford Geertz's "theater state" may also serve well), refers to a form of ceremonial rule that uses theater and especially opera to legitimate and establish political hegemony. Her examples are European countries, Russia, Australia, and the United States. By the 1860s this type of aesthetic politics was practiced worldwide from Rio de Janeiro to Moscow. ${ }^{32}$ In Egypt, the five entertainment buildings of the khedive formed the public infrastructure of the new state culture, though the palaces of the dynasty equally served as scenes of cultural production.

Edward Said misleadingly defined these French or Italian institutions of art, especially the Opera House and the opera Aida, as "an imperial article de luxe purchased by credit for a tiny clientele." 33 In fact, they were significant investments in the new style of political hegemony: the Circus especially attracted large numbers of visitors; the Opera later served a mixed elite audience. The buildings expressed the new style of hegemony to everyone in the city (and beyond, through postcards and photographs). A trusted servant of the dynasty, originally a pharmacist, Paul Draneht Bey (1815?-92), directed these institutions between 1869 and 1879 as the superintendent of the khedivial theaters, dealing only with the French and Italian troupes for whom this infrastructure was created. Draneht was responsible for the selection of artists and repertoire.

Theater in Arabic was not included among these arts of the khedivate. This is partly due to the fact that mimetic performances had not been integrated into the Arabic canon, which was under (re-)construction at this time. Egyptian farces and shadow plays, staged as open-air performances, were satirical, politically critical, often vulgar, and usually conducted in vernacular Arabic. ${ }^{34}$ There is only one report of such a farce being performed in front of Mehmet Ali Pasha. ${ }^{35}$ Intellectual Ottoman Arabs from the 1860s started to turn away from these genres. ${ }^{36}$ By the end of the 19 th century the use of Arabic 
vernacular(s) in public mimetic entertainment had acquired an additional social (class) meaning as belonging to the uneducated, poor, and vulgar.

Yet, during the 1850s and 1860s, modern theater productions took place in Arabic in Ottoman Beirut, pioneered by Marun Naqqash (d. 1855). "Modern" here means staged performances, based on written texts, with the conscious aim to produce something new; they were usually called tiyātrū (from the Italian) or marsah (not the now current masrah). The staging by Naqqash and others of plays in Arabic, usually in fusha $\bar{a}$ and containing popular songs, was an innovative synthesis of the Arabic literary heritage and music theater. ${ }^{37}$ If news ever reached the rulers of Egypt about these professional performances in Beirut, no indication of their interest survives from these years. Nor is there any known attempt to stage written modern plays either in the vernacular or in the learned Arabic language in Egypt before 1870. Khedive Ismail did not order a specific theater building for Arabic performances in Cairo. However, his use of French and Italian theaters intersected with the thought of Ottoman Syrian and Egyptian intellectuals who understood "civilization" as the achievement of moral education and conceived of entertainment not only as a source of pleasure but also as an instrument of progress. ${ }^{38}$

THE CONTROL OF KHEDIVIAL CULTURE AND ARABIC THEATER

IN EGYPT, 1870

From its creation in 1869, the infrastructure of khedivial culture was under tight surveillance because theaters were considered dangerous public spaces for political leaders. For instance, U.S. President Abraham Lincoln was assassinated in a theater in Washington, D.C. in 1865. In Cairo, Ismail Pasha's fear was bolstered when a bomb was discovered in the spring of 1869 in the new Comédie. ${ }^{39}$ Thus, in the first season of 1869-70 at least eight policemen were seated among the audience in the Comédie and the Opera House. ${ }^{40}$ The khedivial theaters were mostly governed by unwritten rules. The superintendent Draneht Bey guarded the "honor" of his master. ${ }^{41}$ The everyday life of the hired European artists was reported to the khedive: for instance, an Italian asked him to intervene on behalf of ballerinas who were badly treated. ${ }^{42}$ An undercover agent, Agent $\mathrm{X}$ (as he signed his French reports), spied on the musicians in the orchestra. ${ }^{43}$

It is due to another such agent's report to a police inspector, who transferred it directly to the cabinet of the khedive, that we have the earliest information about modern theatrical experiments in Arabic in Egypt. Writing in French, "Agent Z" reported that young Egyptians in Cairo in 1870 wanted to stage the play Alexandre dans les Indes, which had been translated into Arabic. This French title may refer to an Italian libretto, Alessandro nell'Indie (1729, Pierro Metastasio), which was set to music in almost seventy versions, most famously in Giovanni Pacini's opera (premiered in 1824). The agent had probably translated the Italian title into French for his report. Agent $\mathrm{Z}$ noted that "the population" in Cairo desired theater in Arabic, and that this interest derived from a combination of influences: a book of Arabic dramas printed in Beirut (probably Niqula Naqqash, ed., Arzat Lubnan, 1869); a speech about Arab theater buildings delivered in the spring of 1870 in Cairo's New Hotel (probably by the architect Hector Horeau); and Arabic translations of libretti (Don Juan, Moïse, Barbier du Seville). Members of the affluent Egyptian Jewish Qattawi family also wished to stage Arabic dramas in their own house but had to postpone the plan due to a family tragedy. Unusually, Agent Z 
suggested to the government that it should support theater in Arabic with a view to educating the masses, by erecting a national theater building and "a school of acting and music," as well as by introducing a copyright law. The suggestion did not specify whether by "Arabic" it meant fuṣha or vernacular. The project advanced by Agent Z would serve to "enlighten" the people, luring ordinary Egyptians to the theater rather than leaving them to "sing obscene songs" in the cafes. Thus theater in Arabic would usher in a new morality to Egypt. ${ }^{44}$

This report contains references to education, civilization, nationhood, and progress. If my identification of Arzat Lubnan is correct (in 1870 there was no other book containing more than one drama in Arabic), then the impact of the Beiruti Arabic theater on the beginnings of Egyptian theater is worth noting. The reports confirm that Khedive Ismail himself was interested in the supervision of khedivial culture in Cairo. This control was directed more over the employed Europeans than the Egyptian subjects (or at least equally over both), because Europeans ran the theaters. Agent $\mathrm{Z}$ reported on a cultural experiment outside of such control and suggested with patriotic arguments that it should be incorporated into khedivial culture.

THE IDEA OF THEATER IN ARABIC: UNSI, JALAL,

AL-MUWAYLIHI, MUBARAK

The aborted experiment of the young Egyptians in Agent Z's report took place within a vivid intellectual atmosphere in Cairo. Translations of libretti (ordered by the khedive) by $\mathrm{Abu}$ al-Su'ud Effendi, the editor of the journal Wadi al-Nil, and other translations (ordered by Draneht Bey) were printed in $1869 .{ }^{45}$ These were not public texts for sale but were probably distributed to Arabic-speaking members of the audience in the Comédie and the Opera House. Translations were also made from Arabic to Ottoman Turkish, and from Italian to French. ${ }^{46}$ The khedive paid for a seat at the Opera for the editor of Wadi al-Nil along with European journalists. Based on his experience there, Muhammad Unsi, the son and fellow editor of Abu al-Su'ud Effendi, called for translations of European plays and for "performing in Egyptian theaters in Arabic" in February 1870 in the journal. ${ }^{47}$

In November, Donizetti's La Favorite and Rossini's Il Barbiere di Siviglia were printed in Arabic at the press of a rich Egyptian, Ibrahim al-Muwaylihi, ${ }^{48}$ and were sent to Wadi al-Nil for distribution with an informal letter from the chief of police. One of these is among the libretti Agent $\mathrm{Z}$ alludes to. In the introduction to the translations, theater is held up as a means of civilization and progress. No translator is credited, so Wadi al-Nil assumed it was Muhammad 'Uthman Jalal, although Jalal never mentioned such an undertaking. ${ }^{49}$ Perhaps Jalal was thought to be the translator because of his previous association with al-Muwaylihi and because his translation of La Fontaine ('Uyun alYawaqiz fi al-Amthal wa-l-Mawa ${ }^{\mathrm{i}}$ iz) was reprinted the same year. ${ }^{50}$ To sum up, texts in Arabic were published to spread the idea of theater in Egypt, including Unsi's call for performances in Arabic, during 1869 and 1870. This is the context to which Agent Z refers in January 1871.

The idea of modern performances in Arabic developed further that year. In the spring of 1871, the regional Arabic press seemed, in different ways, to seek to convince the khedive of the necessity of an Arabic-language theater. The readers of Arabic periodicals 
were also informed about Armenian actors performing in Turkish in Istanbul. ${ }^{51}$ While Wadi al-Nil continued to publish theater news in Cairo (even the last extant issue of 18 March 1871 advertised the opera Semiramis), the correspondent of the Istanbul-based al-Jawa'ib described theaters as signs of progress in April $1871 .^{52}$ In May, al-Jinan in Beirut proposed the establishment of Arab theaters to the Egyptian government. ${ }^{53}$ In Egypt, from May to July 1871, Rawdat al-Madaris published pages from 'Uthman Jalal's translation of Molière's Le Médicin Malgré Lui under the title al-Fakhkh al-Mansub lil-Hakim al-Maghsub. Jalal Egyptianized both the language (using an unrhymed Cairene dialect) and the plot because 'Ali Mubarak, now Director of Schools and editor of Rawdat al-Madaris (and an old schoolmate of Ismail Pasha) had "instructed" him to do so. ${ }^{54}$ 'Ali Mubarak must also be named, alongside Unsi, al-Muwaylihi, and Jalal, as an early supporter of theater in (Egyptian) Arabic. However, the creation of the first theater troupe performing in Arabic was not the work of these Egyptian intellectuals.

MR. JAMES: ARABIC THEATER AS PART OF KHEDIVIAL

CULTURE, $1871-72$

In all likelihood, the first public performance in Arabic by a modern theater troupe took place somewhere in Cairo on 8 July 1871 before a large audience. Al-Jawa'ib remarked that the Cairenes chose al-Qawwas, "an Englishman's play," despite the fact that Arabic plays from Beirut were available to them. ${ }^{55}$ On 27 July, the unnamed troupe performed in front of Khedive Ismail in Qasr al-Nil (where there was a private stage). They started with short pieces in vernacular Arabic written by khawāgha Jams (Mr. James), followed by the performance of two longer and refined plays, al-Bakhil and al-Jawahirji. ${ }^{56}$ This evening was arranged under the direction of Jam 'iyyat Ta'sis al-Tiyatrat al- 'Arabiyya (Society for the Establishment of Arabic Plays). Khawägha James is the only member of this society mentioned in the press. There is no clue as to whether the society is the same as the theater troupe that staged the performances. This evening performance before the khedive might have been a test: was theater in Arabic eloquent enough to be included among the arts of the khedivate?

In October 1871, short comedies/operettas in Arabic were performed again, this time in the Azbakiyya Garden. ${ }^{57}$ Meanwhile, Verdi's Aida, the main cultural project of Khedive Ismail, was premiered on 24 December 1871 in the Opera House. Parallel to this Italian product for the khedivate, by January 1872 the Arabic theater in Azbakiyya had become popular among Egyptians, ${ }^{58}$ but then ceased for some time. In March, al-Jawa $i b$ reported that Khedive Ismail had entrusted the arrangements of the Arabic theater to Mr. James (yatawallā tartībuhu wa-tanzìmuhu), who planned to reopen it on 1 Safar 1289 (10 April 1872) in the Azbakiyya Garden. ${ }^{59}$ By April, the Arab theater (al-malha al- 'arabl) was indeed popular among the "modern and idle people," first with dancing girls from Beirut, then without them. The troupe prepared to perform in the Comédie on 22 April, which was the first occasion of an Arabic performance there. ${ }^{60}$ The Azbakiyya Garden was crowded that month because of rumors that tickets would soon be introduced, replacing the system of free entrance. ${ }^{61}$ In May, the advertisement of an Arabic drama, known as Layla, by the Azhari student Muhammad 'Abd al-Fattah al-Misri, mentioned "the Arabic theater [troupe]" (al-tiyātrū al- 'arab $\vec{\imath})$ "now performing 
in the garden of al-Azbakiyya."62 In the preface of this drama (printed under the title Nuzhat al-Adab fi Shaja 'at al- 'Arab al-Mubhija li-l-A 'yun al-Zakiyya fi Hadiqat alAzbakiyya), the author thanks his friend, "the esteemed director James," for his advice. He also hails James as a pioneer and dedicates the play to Minister of Finance Isma'il Pasha al-Siddiq. ${ }^{63}$

Mr. James' troupe performed Layla at least twice in June and/or July 1872. The first performance was probably part of the garden's inauguration. ${ }^{64} \mathrm{Le} \mathrm{Nil}$ reports that in the theater of "M. [Monsieur] James" the audience thought that the actors had actually killed each other during the performance and, when reassured to the contrary, demanded an encore. ${ }^{65}$ This is the last contemporary report available on the theater of Mr. James. ${ }^{66}$ The evidence thus establishes that he was entrusted by Khedive Ismail to organize a theater in the Azabkiyya Garden and that he was active in that theater between July 1871 and July 1872.

UNSI STRIKES BACK, 1872

Only one indirect reaction to the troupe of Mr. James could be retrieved from among the Egyptian intellectuals who were already interested in theater. In fact, this is a rival proposal to introduce Arabic-language theater into the arts sponsored by the khedive. It came from the journalist Muhammad Unsi, who first demanded Arabic performances in 1870. In his journal, Wadi al-Nil, Unsi was supportive of Mr. James in the summer of $1871,{ }^{67}$ but this attitude seems to have soon changed. As shown by Sadgrove, in March 1872, Unsi along with the teacher Louis Farrugia submitted a petition in French, through Draneht Bey, to Ahmet Hayri Pasha (Ahmad Khayri, 1824-86), the mühürdar (sealbearer, personal secretary) of Khedive Ismail. It contained a detailed project to establish an Egyptian Arab National Theater with a school; it emphasized, possibly alluding to Mr. James, that "the experiment did not bring a good result," and pointed out that it was Unsi who had originally coined the idea of a theater in Arabic. This vision of a theater combined with a school was similar to Agent Z's 1871 suggestion, but differed from it in proposing the use of literary Arabic and the corpus of medieval literature as a source for theater. This institution was imagined as being under the administration of Draneht Bey, like all the other khedivial theaters. It is hard to miss in Unsi's project the intellectual's desire to shape the official Egyptian Arabic culture according to his own taste. ${ }^{68}$ This proposal, not surprisingly, was supported by Draneht Bey. But who was Mr. James?

\section{MR. JAMES AND MR. JAMES SANUA}

In determining the identity of Mr. James, I see two options. The first is to accept that he was an Englishman who composed and staged Arabic plays in Cairo in 1871-72 and was entrusted by Khedive Ismail with the direction of the Arabic theater in the Azbakiyya Garden. Given the pashas' frequent use of the expertise of foreigners, this is not an unimaginable scenario. In this case, we must conclude that an Englishman headed the first official Arabic-language theater in Egypt. ${ }^{69}$

The second option is that Mr. James was James Sanua. I have three arguments to support this identification. First, the name of James Sanua as the author of five Arabic plays and the director of the Arabic theater was mentioned in L'Égypte on 11 May 1872. An Arabic summary of this French article, published in $a l$-Jawa'ib, expressed hope for 
khedivial support of mistar Jāmis Sanuwā mudīr al-tiyātrū al- 'arabī (Mr. James Sanua, the director of the Arabic theater).$^{70}$ Thus, either Mr. James and James Sunua were the same person, or there were two Arabic theater troupes in Cairo in May 1872.

Second, in these years Sanua was referred to as "James" (in Egyptian Arabic, "Gems") and sometimes as "Mr. James," by himself and others, rather than as Ya'qub, his original given name and the one by which he is usually mentioned in the scholarship today. In his 1868 certificate of freemasonry (La Concordia lodge) his name is written as "James Sanua" in English and "Jacobum Sanua" in Latin. ${ }^{71}$ In 1869 he published a book in Italian under the name James Sanua, entitled L'arabo anziano ("The Old Arab," examined below). ${ }^{72}$ Abd al-Fattah mentions his friend Jams Sānū in his first book, published in $1869,{ }^{73}$ and Sanua is called James in the above-mentioned 1872 article of al-Jawa $i b$. He published plays in Italian under the name James Sanua in 1875 (L'aristocratica alessandrina) and 1876 (Il marito infedele). ${ }^{74} \mathrm{He}$ wrote his name in Arabic as Jams Sānūwa in the spring of 1878, and referred to himself as khawāgha Jams. ${ }^{75}$ In a posthumously published play, he thanks the audience in the name of "Mr. James and the actors." ${ }^{\text {"76 }}$ We have only post- 1877 evidence that he used the pen name Abu Naddara when writing in French or Arabic. ${ }^{77}$ As late as 1879, "Professor James Sanua" edited the journal Abu Naddara in Paris. ${ }^{78}$ John Ninet, who knew him in Egypt, called him James Sanua. ${ }^{79}$ Sanua and his family used the name James privately. ${ }^{80}$ It is only after Philip de Tarrazi's standardization in $1913^{81}$ that researchers started to use Ya $^{c} q u b .{ }^{82}$ This is justified in part because the only separately printed play at the end of his life, Mulyir Misr wa-ma Yuqasihi (1912), dedicated to Tarrazi, gives the name of the author as $Y a^{c} q \bar{u} b S a n \bar{u}^{c}$ on the title page, though in the text he refers to himself as "James." 83 If he was known as Mr. James, the editors of al-Jawa'ib and even the Egyptian Wadi al-Nil may have assumed that the name referred to an Englishman.

My third argument is based on the fact that Sanua asserted several times that he established the first theater in Arabic in Egypt. In an 1876 phrase book he defined himself as "professeur de langues et auteur du théâtre arabe" and in 1878, while still in Egypt, he claimed to be the "founder of Arabic theater plays" (mu'assis al-tiyātrāt alcarabiyya). ${ }^{84} \mathrm{He}$ often noted later, in Arabic and French, that he initiated the Egyptians to theater ${ }^{85}$ (although he never stated explicitly that he was the first to perform plays in Arabic in Egypt). ${ }^{86}$ The title page of the play Mulyir Misr announces him again as "the founder of Arabic theater plays." It is unlikely that Sanua could have maintained such public assertions in Arabic and French if an Englishman had preceded or rivaled him. How did Sanua become interested in Arabic theater and what did this interest entail?

\section{RECALIBRATING THE BEGINNING: THE ITALIAN-EGYPTIAN CONTEXT}

Let us start from the beginning again in order to discover Sanua's background. According to his memoirs, he arrived at the idea of a theater in Arabic during the summer of 1870 by watching Italian and French troupes. ${ }^{87}$ In his narrative, he studied Italian, French, and English plays and hastily trained his young Egyptian students as members of his Arabic troupe. ${ }^{88}$ Though he never mentions it, his book L'arabo anziano, published in 1869 , illustrates an earlier engagement with satire and allows a glimpse into his Italian context. 
L'arabo anziano was dedicated to Marco de Morpurgo di Nilma (a Jewish banker in Trieste and Alexandria) on 30 September $1869 .{ }^{89}$ Since Sanua's father was a Jew from Livorno, Sanua was educated there, he was an Italian protégé, and this was the language of his freemason lodge, the Italian language may have a hitherto unacknowledged importance in his early life. ${ }^{90}$ The book might be an example of eastern Mediterranean Italian-speaking Jewish culture; it is certainly a typical instance of Italian satire in Egypt. The literary mask of the "old Arab" is the continuation of a specific literary trick of using "Arab" topics in poems that already had appeared in the Italian journals of Alexandria in the 1850s. ${ }^{91}$ L'arabo anziano contains poems and two short dialogues in Italian. Sanua's love for Egypt ("veramente io ami il nostro Egitto," "I really love our Egypt") is expressed in the preface but the poems' main theme is the criticism of religion.

The two dialogues deal with sensitive topics. In the first, entitled "Il Discorso di Napoleone III-Dialogo Fra Ali e Mustafa" (The Speech of Napoleon III—A Conversation between Ali and Mustafa), two Muslim Egyptians discuss the news. Mustafa reads a journal aloud to Ali. They are wondering about the identity of Napoleon (III), who made a speech in the Senate, and find out that he is "our lawyer" ("nostro avvocato"). This is an ironic allusion to Napoleon III's earlier role in the negotiation between the Suez Canal Company and Khedive Ismail. The second dialogue, "Il Principe di Galles-Dialogo Tra Saleh e Mohammed" (The Prince of Wales-A Conversation between Saleh and Mohammed), takes place again between two Muslim Egyptians. Saleh and Mohammed mock the antiquity-loving Prince of Wales (who visited Egypt in February and March 1869). ${ }^{92}$ The language is colloquial Italian with some expressions in colloquial Egyptian. It is not clear who are the butts of the humor: Europeans, Egyptians, or both.

The relation of this Italian book in 1869 to Sanua's supposed inspiration for Arabic theater in the next year is unclear. There is no indication of staging intentions, and the use of footnotes suggests that the short texts were created to be read. Though the two dialogues are not complete comedies, they give evidence of a budding theatrical talent. ${ }^{93}$ Even if Sanua's direct inspiration for Arabic theater might have arisen from watching the visiting western Europeans, he was already seasoned in dialogue writing. L'arabo anziano suggests that his social milieu was the Italian-speaking mixed semi-bourgeois strata in Cairo whose members considered themselves Egyptian.

\section{AN OFFER TO THE KHEDIVE}

From the above reconstruction, I understand Sanua's Arabic initiative as an effort by an individual of local birth not belonging to the dominant groups to recast himself as the representative of a new political community in the framework of a new state. I also argue that Sanua's imagination of this ideal political community at this period in Cairo (1868-72), as far as it can be reconstructed, was a non-religious cultural unity in which the Ottoman Egyptian ruler joined non-Muslim and Muslim Egyptians in the joy of modern theater in Arabic.

Sanua wanted to reach the khedive directly. According to his account, he did not approach Draneht Bey (the superintendent of khedivial theaters) but rather Ahmet Hayri Pasha (the same notable to whom Unsi's proposal would be sent), the seal-bearer of the ruler. Sanua presented this important Circassian member of the Ottoman-Egyptian elite with the manuscript of his first play, an operetta in Egyptian Arabic. He could do 
this because Hayri worked as a tutor of Ahmet Yeğen Pasha's children before being attached to the court ${ }^{94}$ and, since Yeğen Pasha had sponsored Sanua's education in Italy, they must have known each other. Sanua also remembers that before the first public performance the musicians played "the khedivial anthem" and then he gave a speech praising Khedive Ismail. ${ }^{95}$ Sanua apparently wanted to convince the khedive and the audience that his troupe was motivated by loyal sentiments.

The troupe was possibly helped by Hayri Pasha as well as by two coincidences. The first was the opening of the Azbakiyya Garden, including a small theater (ThêatreConcert du Jardin de l'Esbekieh) and kiosks as new entertainment spaces, on 1 June 1871, while they were still unfinished. ${ }^{96}$ In his memoirs Sanua dates the first performance to 1870 in the "théâtre-concert," but regardless of when the troupe began private performances, its public performances could not have started before June 1871 in this space. A. J. Rosenboom, the conductor of the Comédie's orchestra, was promised the concession of this new theater, and in April 1871 he was named its "titulaire definitive" (final holder of rights). ${ }^{97}$ By the end of May, he even had his own letterhead: "Administration du Théatre-Concert du Jardin de l'Esbekieh au Caire-Direction de MAJ Rosenboom." Thus it was a unit separate from Draneht's superintendence or at least not under his direct supervision. The second coincidence was that Draneht spent the summer in Italy and France, dealing with the arrangements for Aida, from late April until the end of September $1871 .^{98}$ During his absence, the architect Pierre Grand Bey held the keys of the khedivial theaters. ${ }^{99}$ Thus, whatever happened in Cairo at this time, Draneht Bey had no direct control. It is in this context that the theater troupe made its debut appearance and performed even in front of the khedive in July 1871. Sanua managed to reach the ruler directly. What did the troupe put on stage?

THE REPERTOIRE OF SANUA'S TROUPE AND (THE LACK OF)

HISTORY ON STAGE

The study of the repertoire can determine whether the ideology of this enterprise was an early Middle Eastern expression of radical ideas or at least of anti-khedivial nationalism, as is often supposed. Even if the historical reconstruction allows us to see the troupe within the frames of khedivial culture, the plays may testify to a subversive agenda. ${ }^{100}$ I propose to approach the repertoire of the troupe bearing in mind an elite technique of theater. The central feature of this technique is the evocation of a past event (a battle, a hero, a myth, a martyrdom) as a reference point for the unifying emotional identification through which national unity, or at least the experience of such an imagined unity, may emerge. It does not have to be historical; it is enough to be historicized. Opera is perhaps the main genre of this type of cultural nationalism in the 19th century, exemplified by the works of Richard Wagner, Giuseppe Verdi, and Bedřich Smetana. Myths, battles, and heroes are represented in a standardized national and musical language for middle-class or elite audiences, often drawing a moral conclusion. The "national imagination" not only finds its home in novels ${ }^{101}$ but might also be experienced collectively in the theater. Do we find this technique in the plays performed by Sanua's troupe?

There was one play in the repertoire that employs this technique. This is Muhammad 'Abd al-Fattah's Layla, a historicized Arab tribal love-tale resulting in a bloodbath. This tragedy, with its educated language (though some vernacular words, such as ashüf, are 
interspersed), including a quotation of the ancient poet 'Antara bin Shaddad, evokes a moral concept of Arabness. For instance, the father Amir Zaydan warns the hero Hasan not to employ any trick against his rival because "treason is not an Arab or heroic quality" (al-khiyāna laysa hiya min sha'n al- 'arab wa-l-fursān). ${ }^{102}$ When the rival lover, Amir 'Imran, plays false, Amir Zaydan accuses him not being an Arab because Arabs "do not act in this way, tell me, did you go mad?" (al- 'arab laysū kadhālik qul liyya hal tajannanta?). ${ }^{103}$ This tragedy contains the same intellectual principles that are expressed in Unsi's 1872 proposal: the use of fuṣha and the great Arab literary heritage. The early Egyptian formulation of moral Arabism in this tragedy could fit in with the ideal form of a national drama, and indeed it was written, as 'Abd al-Fattah remarked, "for the sons of the homeland." 104 An indication of this intention is Layla's immediate publication, in contrast to Sanua's plays in Arabic, which remained in manuscript.

The bulk of the repertoire was written by Sanua. His comedies were written in colloquial Arabic (mixed with French, Italian, Greek, and fuṣha Arabic). After the critical analysis of Luqa, Moosa, Badawi, and Sadgrove, these can be reconstructed as approximately twelve texts with songs; seven of them were printed posthumously. ${ }^{105}$ The source of humor is language mistakes and mutual misunderstandings. There are no heroes, no battles, no myths. A short dialogue ridicules an English tourist, similarly to the Italian dialogues in L'Arabo Anziano. Six comedies are about love and marriage. The main characters are urban Syrians and Egyptians, members of modestly wealthy Arabicspeaking merchant families, interacting with Frenchmen, Greeks, and Englishmen. The play al-Durratayn is an exception; its male protagonist is a hashish addict and its theme is polygamy. In general, the Egyptian characters do not mention subversive ideas, and this is especially true of the servants (there are also two European maids), who are portrayed neutrally. ${ }^{106}$ On the contrary, the comedy al-Sadaqa praises the government for encouraging foreign investment. ${ }^{107}$ An Egyptian character in al-Amira al-Iskandaraniyya asserts that he would give up his status as a French protégé to become a subject of the khedive again. Another one admires the fact that "the governor of Egypt transformed his kingdom's capital into a garden." 108 Yet, these texts, contrary to Moreh and Sadgrove's interpretation, are not entirely "on themes far from politics." 109 They ridicule ignorance while praising the khedive. In my view, these plays fit in with the reconstructed historical context and confirm that Sanua made an effort to please the ruler.

Despite the claims of Ghunaym, Moosa, and recently Fahmy, Sanua's use of colloquial Arabic is not evidence that he "wrote for the masses." 110 Wadi al-Nil remarks, apropos of the performance in front of Ismail Pasha (July 1871), that Sanua's short pieces were in the colloquial (al-dārija) "in order to ease the practice for the tenacious young men who perform the plays," before putting on the two refined (adabiyya) works. ${ }^{111}$ It is not the masses but the hastily trained young actors who needed the use of colloquial. Only a very limited number of Egyptians could attend the performances in Cairo. It is possible that songs and jokes became popular as part of the oral urban culture but there is no evidence of such dissemination so far. As to Sanua's intentions, he did print some of his texts in the early 1870s, such as the Italian translation of al-Amira al-Iskandaraniyya (L'aristocratica alessandrina, 1875), but he did not venture into Arabic editions.

To sum up, Sanua's troupe provided a venue for Arabic plays to be performed. His own intention at the time, as far as it can be reconstructed, was a loyal offer to the khedive 
using satirical entertainment techniques. He did not understand, or could not use, history or historicization, the principal vehicle of national imagination. But the Azhari student 'Abd al-Fattah did use a historicized plot in Layla. Had the theater troupe existed longer, it might have performed more plays using historical or historicized themes. Though Sanua led the troupe, it had the potential to become a forum for other playwrights in Arabic. Was this potential politically sensitive and did it lead to the closure of the troupe?

\section{THE END}

If the beginning was obscure, the end is dim. Sanua's troupe dissolved sometime in the summer or autumn of 1872. In scholarship it is often accepted that the khedive "banned" the troupe. ${ }^{12}$ This claim is significant because, if true, it would serve as proof that the troupe indeed criticized the ruler. However, given the absence of archival or other data on such khedivial intervention, Sadgrove suggests that financial reasons led to the closure of the theater troupe. ${ }^{113}$ I agree with this assumption: the end is possibly due to the exclusion from khedivial patronage and the lack of private capital.

According to an early article of Sanua, the khedive "ordered the closure of the Arabic theater and did not give me the money that I had invested into it." 114 In his late memoirs, he wrote that after the performance in front of the khedive in the Comédie in 1872, the ruler, convinced by "the British" about the anti-khedivial content and reaffirmed by the envious Draneht Bey and 'Ali Pasha Mubarak, had the theater (troupe) closed. This was supposedly due to the performance of al-Durratayn the same night. ${ }^{115}$ Sadgrove dates this event to autumn $1872,{ }^{116}$ but as we have seen, the troupe reportedly prepared for a performance in the Comédie in April and Layla was staged in Azbakiyya in July 1872. Thus after the khedive had watched it in the Comédie, the troupe continued to perform in the Azbakiyya Garden until mid-summer 1872. The last known play on stage, according to the contemporary sources, was Layla, the Arab tragedy. At this time Ismail could not ban the troupe, at least not directly, because at the end of June he arrived in Istanbul, where he spent the rest of the summer. ${ }^{117}$ The khedive or Draneht Bey did not include the troupe in the state-supported entertainments. Also, the introduction of the entrance fee in June 1872 in the Azbakiyya Garden must have significantly reduced the audience. In the absence of khedivial patronage and private capital, the members of the troupe looked for other means of living.

Sanua did not continue staging theater plays with a new group after this summer. He possibly made an attempt in 1873 , and he put on an Italian comedy in Cairo in 1877 , but this comeback was deemed a miserable failure in the eyes of the public. ${ }^{118} \mathrm{He}$ included some new plays in Arabic in his journal Abu Naddara in 1878 and the dialogue remained a frequently used genre. ${ }^{119}$ Indeed, considering his Italian dialogues in L'arabo anziano, it seems to have been his favorite literary device. The other Egyptians who were interested in theater in Arabic_ C Ali Pasha Mubarak, 'Uthman Jalal, and 'Abd al-Fattah al-Misri-continued to produce theater-related texts in Arabic. Yet, no khedivial reply to Muhammad Unsi's petition has survived and his journal, Wadi al-Nil, also ceased around this time. 
EARLY KHEDIVIAL CULTURE AND PATRIOTIC PROSPECTS,

$1868-72$

The question arises as to why both Sanua and Unsi asked for the support of the khedive in establishing a theater. Why did they not establish a private theater troupe to perform plays in Arabic, as had been done in Beirut (and in line with private troupes performing in Ottoman Turkish in Istanbul and in French, Italian, English, Hungarian, and Czech in European capitals)? Why did they seek the support of important members of the court? Why, as I have argued, was Sanua's troupe an offer to the khedive?

First, there were no private theater buildings in Cairo at this time. Had they begun a project in Alexandria, where there were a number of private theater buildings, a very different outcome might have emerged. Next, they may have doubted the profitability of a private troupe given the lack of an established practice of theater attendance among Egyptians. Sanua or Unsi might also have hoped for khedivial favors because in these early years Ismail Pasha was celebrated in the press as a modernizer. Sanua in fact later wrote that during this period he believed that Ismail was the leader of progress, "a sound man" ( rajul malīh). ${ }^{120}$ (Even 'Abd Allah Nadim, the later anti-khedivial orator, composed a panegyric in Arabic in 1872 praising the dynasty.) ${ }^{121}$ Finally, the patronage of the government was expected because theater was perceived not only as entertainment, or l'art pour l'art, but as we have seen, as a means of public education. In these early years, Arabic theater as a public project in the capital had to be related to the khedivate in the imagination of those who understood this new dynastic state as a progressive Egyptian national monarchy. This perception may have changed soon thereafter but its existence at the time is undeniable, and it was favorable for the ruler, who was expected to become a member and leader of the new cultural polity.

Why, then, did Khedive Ismail not finance Sanua's experiment? This was because the satire, which Sanua had practiced in Italian and then in the Egyptian colloquial, was not an accepted form of patriotic expression in an age when the elite and the learned dictated the construction of the nation. The lack of history or historicization made the plays incompatible with official state culture. As an already noted counter-example, in this period the main project of Ismail was Aida, a grand opera about the ancient Egyptian empire, which he and Draneht conceived as a "national" opera. ${ }^{122}$ Though the lack of history itself can be understood as sign of revolt in the face of this dominant technique, the background, the historical context, and the texts do not contain any further reference to such an ideological position. Unsi's concept of refined Arabic theater and 'Abd al-Fattah's moral tragedy contain much more sophisticated imaginations, which might have been more suitable for khedivial culture in Arabic. The timing and the haste of Sanua might have prevented these early patriotic ideas and objectives from attaining maturity and attracting khedivial sponsorship.

\section{CONCLUSION}

This article has shown how, in the context of a lively Egyptian intellectual interest in theater, from the summer of 1871 until the summer of 1872 a theater troupe under the leadership of James Sanua performed intermittently in Arabic. His printed works in this period were all in Italian, and thus his staging of colloquial Arabic plays is notable. The 
troupe also performed the play Layla by Muhammad 'Abd al-Fattah al-Misri. In the end, the khedive did not invest money into this experiment and the group dissolved.

My analysis suggests that this troupe was a loyal offer to the khedive for the inclusion of Arabic theater among the arts of the khedivate. There is no proof that Sanua wanted to disseminate anti-khedivial propaganda in Arabic at this time. The troupe remained isolated because, clinging to the Ottoman-Egyptian court, Sanua was not well connected to Egyptian intellectuals, did not print his Arabic plays, and later Syrian theater-makers dominated the scene in British-occupied Egypt. This social and temporal isolation explains the complete absence of Sanua's short-lived company from Egyptian cultural memory and his anomalous position in Arabic theater history. However, purging Sanua and his experiment from Egyptian history also leads to the loss of the context of other abortive Egyptian initiatives.

While Sanua's comedies mirrored contemporary local issues in Egypt, 'Abd alFattah's tragedy and Unsi's proposal were largely built on the past and on the Arabic heritage. Yet 'Abd al-Fattah and Unsi cannot be categorized as early representatives of cultural Pan-Arabism, since in their understanding Arab history and the learned language expressed their love of territorial Egypt. Their cultural expressions contain allusions to a historically Arab or Arabic Egypt. As a third technique for creating plays, 'Uthman Jalal's Egyptianization of French dramas must be also noted. These are three clearly differing methods to achieve theatrical texts. But all alluded to Ismail Pasha as the leader of progress in Egypt. While early khedivial culture incorporated Egypt into the global regime of art, this story discloses moments when local discourses about homeland and theater in Arabic attempted to include the Ottoman khedive within the plural cultural bodies of Egypt.

\section{NOTES}

Author's note: The first version of this article was written when I was a 2011/2012 Fellow of the "Europe in the Middle East-The Middle East in Europe" program of the Wissenschaftskoleg zu Berlin hosted by the Zentrum Moderner Orient. I am grateful for the directors of this program; for the suggestions of Lale Can, Eliane Ettmüller, Mohamed-Salah Omri, and Abhishek Kaicker; for the English corrections of George Taylor; and for the critical comments of four anonymous reviewers and the IJMES editors, Beth Baron and Sara Pursley. I alone am responsible for all remaining mistakes.

${ }^{1}$ Since the publication of Philip Sadgrove's The Egyptian Theatre in the Nineteenth Century 1799-1882 (Cairo: American University in Cairo Press, 2007 [1996]), Sayyid 'Ali Isma'il has focused on 19th-century Egyptian theater history. See Sayyid 'Ali Isma'il, Ta’rikh al-Masrah fi Misr fi al-Qarn al-Tasi ' 'Ashar (Cairo: Maktabat al-Usra, 2005 [1997]); Ta'rikh al-Masrah fi al-'Alam al-'Arabi (al-Qarn al-Tasi' 'Ashar) (Kuwait: Mu'assasat al-Marjah, 1998); and Muhakamat Masrah Ya'qub Sanu'(Cairo: al-Hay’a al-Misriyya al-'Amma li1-Kitab, 2001). Most reviews of Isma 'il's books are accessible on his website (http://kenanaonline.com/sayedesmail), and the introduction of Muhakamat also contains references to his reception in the Kuwaiti press. Muhammad Yusuf Najm's main works in theater history are al-Masrahiyya fi al-Adab al- 'Arabi al-Hadith, 1847-1914, 2nd ed. (Beirut: Dar al-Thaqafa, 1967), and a number of text editions, including Sanua's eight plays in Ya'qub Sannuc - Abu Naddara (al-Masrah al-'Arabi-Dirasat wa-1-Nusus 3) (Beirut: Dar al-Thaqafa, 1963). Najm challenged Isma'il in "Riyadat Sanu' li-l-Masrah Haqiqa ... wa-hadhihi hiya al-Adilla," alAhram al-Masa'i (5 March 2001). Isma'il replied in "Muhakamat Masrah Sanu' ... ma Zalat Mustamirra," al-Ahram al-Masa'i (12 March 2001). Najm also published his critique in Akhbar al-Adab (25 March 2001), to which Isma'il replied in the same journal (8 April 2001). This heated debate continued for a time; in 2001 and 2002, poets, journalists, and playwrights contributed to it in the Kuwaiti al-Watan and the Egyptian al-Muhit, al-Akhbar, and al-Ahram al-Masa'i. A later contribution is Muhsin al-Musaylihi, Su'ali: Man 


\section{Adam Mestyan}

Kataba Masrahiyyat Ya'qub Sanu'? (Cairo: Akadimiyyat al-Funun, 2005). Najm's last word was probably the republication of Muhammad 'Abd al-Fattah al-Misri's play Nuzhat al-Adab fi Shaja'at al- 'Arab al-Mubhija li-l-A 'yun al-Zakiyya fi Hadiqat al-Azbakiyya as Lu'bat Layla (Beirut: Dar Sadir, 2002 [1872]), discovered and analyzed by Philip Sadgrove, "Leyla - The First Egyptian Tragedy," Osmanlı Araştırmaları 7-8 (1988): 161-76.

${ }^{2}$ See his series of articles in al-Jumhuriyya during 2010-2011: for example, "Tahwid al-Masrah al-'Arabi" (The Judaization of Arab Theater), 31 October 2010.

${ }^{3}$ Ziad Fahmy, "Francophone Egyptian Nationalists, Anti-British Discourse, and European Public Opinion, 1885-1910: The Case of Mustafa Kamil and Ya'qub Sannu'," Comparative Studies of South Asia, Africa and the Middle East 28 (2008): 170-83, esp. 176.

${ }^{4}$ Ibrahim 'Abduh, Abu Nazzara-Imam al-Sihafa al-Fukahiyya al-Musawwara wa-Za'im al-Masrah fi Misr, 1839-1912 (Cairo: Maktabat al-Adab bi-Darb al-Jamamiz, 1953), 17.

${ }^{5}$ Irene L. Gendzier, “James Sanua and Egyptian Nationalism,” Middle East Journal 15 (1961): 16-28, esp. 17.

${ }^{6}$ Lisa Lital Levy, "Jewish Writers in the Arab East—Literature, History, and the Politics of Enlightenment, 1863-1914" (PhD diss., University of California, Berkeley, 2007), 142, 166.

${ }^{7}$ Jacob M. Landau, "Abu Naddara, an Egyptian-Jewish Nationalist," The Journal of Jewish Studies 3 (1952): 30-44; idem, Jews in Nineteenth-Century Egypt (New York: New York University Press, 1969), 12.

${ }^{8 c}$ Abduh, Abu Nazzara, 26.

${ }^{9}$ Gendzier, "James Sanua and Egyptian Nationalism," 20.

${ }^{10}$ Shmuel Moreh and Philip Sadgrove, Jewish Contributions to Nineteenth-Century Arabic Theatre (Journal of Semitic Studies Supplement 6) (Oxford: Oxford University Press, 1996), 21.

${ }^{11}$ Ziad Fahmy, Ordinary Egyptians: Creating the Modern Nation through Popular Culture (Stanford, Calif.: Stanford University Press, 2011), 45.

${ }^{12}$ 'Abd al-Hamid Ghunaym, Sanu'-Ra'id al-Masrah al-Misri (Cairo: Dar al-Qawmiyya li-1-Tiba'a wa-1Nashr, 1966), unpaginated (p. 5).

${ }^{13}$ cAbduh, Abu Nazzara, 26-27; Fahmy, Ordinary Egyptians, 46.

${ }^{14}$ Irene L. Gendzier, The Practical Visions of Ya' qub Sanu' (Cambridge, Mass.: Harvard University Press, 1966), 3.

${ }^{15}$ Anwar Luqa, "Masrah Ya'qub Sanua'," al-Majalla, 5 (1961): 51-71; Matti Moosa, "Ya'qub Sanuc and the Rise of Arab Drama in Egypt," International Journal of Middle East Studies 4 (1974): 401-33; Najwa Ibrahim Fu’ad 'Anus, Masrah Ya 'qub Sanu 'Cairo: al-Hay’a al-Misriyya al-'Amma li-1-Kitab, 1984); Muhammad Mustafa Badawi, "The Father of the Modern Egyptian Theatre: Ya'qub Sannu'," Journal of Arabic Literature 16 (1985): 132-45, esp. 134; Sadgrove, The Egyptian Theatre, 89-124. Contemporaries already called attention to Sanua's self-aggrandizing personality: "On remarquera peut-ètre que le Molière égyptien se taille un rôle qui ne brille pas précisement par la modestie." Paul de Baignieres, Album d'Abou Naddara (Paris: Imprimerie Lefebvre, 1886), 16.

${ }^{16}$ Luqa, "Masrah Yacqub Sanua'," 52.

${ }^{17}$ Moosa, "Ya'qub Sanu'," 408.

${ }^{18}$ Alexander Schölch, Egypt for the Egyptians! The Socio-political Crisis in Egypt, 1878-1882 (London: Ithaca Press, 1981), 107-108, 121.

${ }^{19}$ In addition to the works cited above, see Mas'ud Hamdan, Poetics, Politics and Protest in Arab Theater: The Bitter Cup and the Holy Rain (Brighton: Sussex Academic Press, 2006); Mohamed Garfi, Musique et spectacle: le théâtre lyrique arabe. Esquisse d'un itinéraire (1847-1975) (Paris: L'Harmattan, 2009); Ilham Khuri-Makdisi, The Eastern Mediterranean and the Making of Global Radicalism (Berkeley, Calif.: University of California Press, 2010); Carmen M. K. Gitre, "Performing Modernity: Theater and Political Culture in Egypt, 1869-1923” (PhD diss., Rutgers University, 2011); Adam Mestyan, “A Garden with Mellow Fruits of Refinement': Music Theatres and Cultural Politics in Cairo and Istanbul, 1867-1892" (PhD diss., Central European University, 2011); and Eliane Ursula Ettmüller, The Construct of Egypt's Nation-Self in James Sanua's Early Satire and Caricature (Berlin: Klaus Schwarz Verlag, 2012).

${ }^{20}$ Fahmy, Ordinary Egyptians, 7.

${ }^{21}$ I use the Turkish spellings of names of the Ottoman-Egyptian ruling elite.

${ }^{22}$ Reem Bassiouney (Arabic Sociolinguistics [Edinburgh: Edinburgh University Press, 2009], 14-19) and Ziad Fahmy (Ordinary Egyptians, 5-11) argue that the Arabic linguistic situation cannot be reduced to a 
simple case of diglossia containing a high and a low language. However, I do not provide further distinctions, since the argument of this essay is not linguistic.

${ }^{23}$ Ekmeleddin İhsanoğlu, The Turks in Egypt and Their Cultural Legacy, trans. Humphrey Davis (Cairo: American University in Cairo Press, 2012), 39-79.

${ }^{24}$ There is an urban legend that Abbas liked "Arabs" because his mother was an Egyptian (Arab). John Ninet, "Origin of the National Party in Egypt," The Nineteenth Century (1883): 117-34. This is incorrect; Abbas was the son of Tusun Pasha and Penbe Hanım, a Turkic woman. For his Arabic language skills, see Murray to Walne, 20 September 1850, FO 78/841, appendix in Helen Anne B. Rivlin, "The Railway Question in the Ottoman-Egyptian Crisis of 1850-1852," Middle East Journal 15 (1961): 365-88.

${ }^{25}$ Dyala Hamzah, "Nineteenth-Century Egypt as Dynastic Locus of Universality: The History of Muhammad 'Ali by Khalil ibn Ahmad al-Rajabi," Comparative Studies of South Asia, Africa and the Middle East 27 (2007): 62-82.

${ }^{26}$ Iskandar Abkariyus, al-Manaqib al-Ibrahimiyya wa-l-Ma'athir al-Khidiwiyya (Homs: Matba'at Hims, 1910), 87-91.

${ }^{27}$ Hadiqat al-Akhbar, 17 Dhu al-Qa'da 1275 (18 June 1859), 3.

${ }^{28}$ Shmuel Moreh, Modern Arabic Poetry (Leiden: E. J. Brill, 1976), 18-19.

${ }^{29}$ Mohammed Sabry, La genèse de l'esprit national égyptien (Paris: [Libraire Picart], 1924), 98.

${ }^{30}$ For popular colloquial poetry, see Pierre Cachia, Popular Narrative Ballads of Modern Egypt (Oxford: Clarendon Press, 1989); Marilyn Booth, "Colloquial Arabic Poetry, Politics, and the Press in Modern Egypt," International Journal of Middle East Studies 24 (1992): 419-40; and Margaret Larkin, "Popular Poetry in the Post-Classical Period, 1150-1850," in The Cambridge History of Arabic Literature, vol. 6, ed. Roger Allen and D.S. Richards (New York: Cambridge University Press, 2006), 191-242.

${ }^{31}$ Nadia Al-Bagdadi, Vorgestellte Öffentlichkeit (Wiesbaden: Reichert Verlag, 2010).

${ }^{32}$ Ruth Bereson, The Operatic State: Cultural Policy and the Opera House (London: Routledge, 2002).

${ }^{33}$ Edward W. Said, Culture and Imperialism (New York: Vintage Books, 1993), 129.

${ }^{34}$ Ehud Toledano, State and Society in Mid-Nineteenth-Century Egypt (Cambridge: Cambridge University Press, 1990), 231-33.

${ }^{35}$ Edward William Lane, Manners and Customs of the Modern Egyptians (The Hague and London: East-West Publications, 1978), 384-85.

${ }^{36}$ Ali Pasha Mubarak, 'Alam al-Din, 2 vols. (Alexandria: al-Mahrusa, 1882), 2:403-404; Thomas Philipp, $\breve{G u r g ̆ i ~ Z a i d a n-H i s ~ L i f e ~ a n d ~ T h o u g h t ~(B e i r u t: ~ F r a n z ~ S t e i n e r ~ V e r l a g, ~ 1979), ~ 142-43 . ~}$

${ }^{37}$ Matti Moosa, "Naqqash and the Rise of the Native Arab Theater in Syria," Journal of Arabic Literature 3 (1972): 106-17; Philip C. Sadgrove, "The Syrian Arab Theatre after Marun Naqqash (the 1850s and the 1860s)," Archív Orientálni 55 (1987): 271-83.

${ }^{38}$ Niqula Naqqash, ed., Arzat Lubnan (Beirut: al-Matba'a al- ${ }^{\circ}$ Umumiyya, 1869), 4-28; for an analysis of Marun and Salim Naqqash's ideas about theater as a social instrument, see Khuri-Makdisi, The Eastern Mediterranean, 63-67. See also Rifa 'a Rafi ' al-Tahtawi, al-Diwan al-Nafis fi Iwan Baris, aw Takhlis al-Ibriz fi Talkhis Bariz (Beirut: al-Mu’assasa al- 'Arabiyya li-1-Dirasat wa-l-Nashr, 2002 [1834]), 139-41. In general, see Muhammad Kamil al-Khatib, ed., Nazariyyat al-Masrah (Damascus: Manshurat Wizarat al-Thaqafa, 1994); and Reinhard Schulze, "Schauspiel oder Nachahmung? Zum Theaterbegriff Arabischer Reiseschriftsteller im 19. Jahrhundert," Die Welt des Islams 34 (1994): 67-84.

${ }^{39}$ Levant Herald, 5 April 1869, 2.

${ }^{40}$ Letter dated 14 January 1870, Draneht to "la Daira des affaires particuliers de Son Altesse le Khédive," Carton 80, Collection 'Ahd Isma 'il (old system), Dar al-Watha'iq al-Qawmiyya (Egyptian National Archives, hereafter DWQ).

${ }^{41}$ Khuri-Makdisi quotes a Theater Regulation (Nizam al-Masrah) from 1874 (The Eastern Mediterranean, 76), based on Najm, al-Masrahiyya, 21-22. The 1874 date is a printing mistake in Najm. The original Italian text is dated 1847, issued by Artin Bey. The original is in DWQ; it was first published by Jeanette Tagher ("Les débuts du théâtre modern en Égypte," Cahiers d'Histoire Égyptienne 1 [1948]: 192-207, esp. 197), then as Appendix 1 in Sadgrove, The Egyptian Theatre. Khuri-Makdisi draws unjustified conclusions; this text regulated one specific theater in Alexandria during Mehmet Ali's rule. There might have been a written regulation for the theaters of Ismail Pasha but Draneht personally controlled all of the theaters' affairs.

${ }^{42}$ Letter dated 29 December 1869, Antoine Banucci to the Khedive, 5013-003022, Usrat Muhammad 'Ali (new system), DWQ. Nicole Lablache was at this moment the administrative director of the Opera House, $L a$ Revue musicale de Paris, 23 May 1869, 174 


\section{Adam Mestyan}

${ }^{43}$ Letter dated 11 January 1871, Agent X to M. Nardi, Inspecteur de Police au Caire, 5013-003022, Usrat
Muhammad 'Ali (new system), DWQ.
${ }^{44}$ Letter dated 27 January 1871, Agent Z to M. Nardi, 5013-003022, Usrat Muhammad 'Ali (new system), DWQ. Hector Horeau (1801-1872), a French architect invited to the Suez Canal Opening Ceremony, gave a lecture in Hotel d'Orient on 7 March 1870. This was advertised in Arabic in Wadi al-Nil, 4 March 1870 (1869 is wrongly printed on the title page), 1347-48 and again, 7 March 1870 (1869 is wrongly printed on the title page), 1363-64.

${ }^{45}$ Sadgrove, The Egyptian Theatre, 48.

${ }^{46}$ For example, Aida was translated into Turkish from Arabic, Letter dated 20 December 1871 from Draneht to Rassik Effendi. The original letter was published in Saleh Abdoun, ed., Genesi dell' 'Aida', con documentazione inedita, Quaderni dell'Istituto di Studi Verdiani 4 (1971), 101, and its English translation in Hans Busch, Verdi's Aida-The History of an Opera in Letters and Documents (Minneapolis, Minn.: University of Minnesota Press, 1978), 266. A bilingual Italian-French edition of the libretto was also printed: Aida-Opera in 4 atti e 7 quadri, parole di A. Ghislanzoni, musica del Comm. G. Verdi, scritta per comissione Sua Altezza Il Khedive per il Teatro dell'Opera del Cairo e rappresentata per la prima volta su queste scene nei mese di Decembre 1871 (Cairo: Tipografia francese Delbos-Demouret, 1871).

${ }^{47}$ Muhammad Unsi, "Mal'ab al-Ubira bi-Misr al-Qahira," Wadi al-Nil, 28 Dhu al-Qa da 1286 (28 February $1870 ; 1869$ is wrongly printed on the title page), 1332 .

${ }^{48}$ Ibrahim al-Muwaylihi's press, al-Matbaca al-Wahbiyya, was established in 1868, according to Ibrahim El Mouelhy Pacha, "Les Mouelhy en Égypte," Cahiers d'Histoire Egyptienne (1949/50): 313-28, esp. 319; however, there are books available in library catalogs printed in this press earlier, from hijri year 1281 (1864-65).

${ }^{49}$ Wadi al-Nil, 20 Shacban 1287 (15 November 1870), 2-3. Sadgrove, The Egyptian Theatre, 58-59, accepts that the translator was 'Uthman Jalal and calls Tartuffe and Le Malade imaginaire "operatic libretti" (The Egyptian Theatre, 100). However, these are not operas (although Le Malade imaginaire contains musical intersections). Carol Bardenstein rejects the idea of Jalal translating libretti, in Translation and Transformation in Modern Arabic Literature: The Indigenous Assertions of Muhammad 'Uthman Jalal (Wiesbaden: Harrassowitz Verlag, 2005), 36.

${ }^{50}$ Since Jalal in his autobiography describes his difficulties with finding a publisher in the 1850 s and somehow vaguely relates that he printed the translation of La Fontaine on his own expense, it has been commonly thought that it was published for the first time in 1870. Moreh and Sadgrove, Jewish Contributions, 20; Bardenstein, Translation and Transformation, 32, n. 20. But the book was first printed in August 1858 (Dhu al-Hijja 1274) (Cairo: Matba'at al-Hajar, 1858); copies could even be bought in Beirut: see Hadiqat al-Akhbar, 12 Muharram 1276 (11 August 1859), 4.

${ }^{51}$ Al-Jawa'ib, 22 February 1871, 2.

${ }^{52}$ Al-Jawa'ib, 12 April 1871, 2.

${ }^{53}$ Al-Jinan as quoted in al-Jawa'ib, 10 May 1871, 2.

${ }^{54}$ Quoted in Bardenstein, Translation and Transformation, 105.

${ }^{55}$ L'Égypte, 9 July 1871, and L'Avvenire d'Egitto, as quoted in Tagher, "Les débuts," 206. Al-Jawa'ib only later reports on the "first night" of the theater, in its issue of 16 August 1871, 2. We can only guess which plays were sent from Beirut; those already in print included plays by Tannus al-Hurr (1863), al-Sayyid Salam Ramadan (1867), Ibrahim al-Ahdab (1868, 1870), Marun Naqqash (plays in Arzat Lubnan, 1869), Sa'd Allah al-Bustani (1870) (years indicate the dates of the published texts).

${ }^{56}$ Wadi al-Nil, quoted in al-Jawa'ib, 27 August 1871, 3; Sadgrove, The Egyptian Theatre, 98.

${ }^{57}$ L'Avvenire d'Egitto, 10 October 1871, quoted in Tagher, "Les débuts," 206.

${ }^{58}$ L'Avvenire d'Egitto, 4 January 1872, quoted in Tagher, "Les débuts," 206.

${ }^{59}$ Al-Jawa'ib, 28 March 1872, 2.

${ }^{60}$ Al-Jawa'ib, 11 April 1872, 2.

${ }^{61}$ Al-Jawa'ib, 17 April 1872, 2.

${ }^{62}$ Al-Waqa'i ${ }^{`}$ al-Misriyya, 7 May 1872, as translated in Sadgrove, "Leyla-The First Egyptian Tragedy," 167-68; this article was also reprinted in Najm's introduction to 'Abd al-Fattah al-Misri, Lu'bat Layla, 1.

${ }^{63}$ 'Abd al-Fattah al-Misri, Lu'bat Layla, 3; Sadgrove, "Leyla-The First Egyptian Tragedy," 164; idem, The Egyptian Theatre, 107-108.

${ }^{64}$ Sadgrove, "Leyla-The First Egyptian Tragedy," 168; Ignaz Goldziher, "Jugend- und Strassenpoesie in Kairo,” Zeitschriften der Deutschen Morgenländischen Gesellschaft 33 (1879): 608-30, esp. 609, n. 3. 
${ }^{65}$ Le Nil, 9 July 1872, quoted in Sadgrove, The Egyptian Theatre, 108.

${ }^{66}$ Somewhat later texts that refer to this theater as James Sanua's include: an article from Le Nil (1873), quoted in Sadgrove, The Egyptian Theatre, 117; Jacques Chelley, "Le Moliére Egyptien," L'Abou Naddara, 1 August 1906, 2-3, who quotes an article from the journal Ezbekié (publisher: Jules Barbier) of 1873 and an issue of the journal Karagöz (publisher: Jablin) of 6 May 1876; and Blanchard Jerrold, Egypt under Ismail Pacha (London: Samuel Tinsley, 1879), 216.

${ }^{67}$ Wadi al-Nil, quoted in al-Jawa'ib, 27 August 1871, 3.

${ }^{68}$ First published as appendix 3 to Sadgrove, The Egyptian Theatre, 186-95. It is in Carton 80, 'Ahd Isma'il (old system), DWQ.

${ }^{69}$ Sadgrove, The Egyptian Theatre, 97, believes that the author of the plays mentioned in al-Jawa'ib (16 August 1871, 2) was indeed an Englishman.

${ }^{70}$ Al-Jawa'ib, 29 May 1872, 2. See also Sadgrove, The Egyptian Theatre, 107.

${ }^{71}$ Ettmüller, The Construct, 63-64.

${ }^{72}$ James Sanua, L'arabo anziano (Cairo: Nouva Tipografia di P. Cumbo, 1869).

${ }^{73}$ Quoted in Sadgrove, "Leyla-The First Egyptian Tragedy," 166.

${ }^{74}$ Published by Jules Barbier, quoted in Sadgrove, The Egyptian Theater, 119; 'Abduh, Abu Nazzara, 214.

${ }^{75}$ Abu Naddara Zarqa', no. 1 (25 March 1878): 4. He also authored an Egyptian Arabic phrase book for travelers in 1876 in which he transliterated his name as "Gems Sanua." James Sanua, Petit souvenir de James Sanua aux voyageurs Européens en Egypte (Cairo: J. Barbier, 1876), 14.

${ }^{76}$ Al-Sadaqa, in Najm, Ya ${ }^{c} q u b$ Sannu', 134.

${ }^{77}$ Sanua signed a letter in 1881 as Abū Nazzāa $r a$ Baydă ', published in Shmuel Moreh, "Ya'qub Sanu': His Religious Identity and Work in the Theater and Journalism, According to the Family Archive," in The Jews of Egypt: A Mediterranean Society in Modern Times, ed. Shimon Shamir (Boulder, Colo.: Westview Press, 1987), 111-29, and Appendix C, "The Correspondence of Sanua," 244-64, esp. 244. In this correspondence, Ibrahim al-Muwaylihi calls him James; Mahmud Zaki addresses him as al-Shaykh Abū Nazzāra; and Philip de Tarrazi in 1911 writes Shaykh. De Baigniers, despite often using his name as Abou Naddara in French, also employs James Sanua, for instance, in Album d'Abou Naddara, 9. Jamal al-Din al-Afghani dedicated a photo to al-Shaykh Jams Abū Nazzāra, printed in 'Abduh, Abu Nazzara, 13. Sanua introduces himself in English to Wilfrid Blunt as "your most humble servant James Sanua, surnamed Abou-Naddara Zarka." Letter dated 11 April 1883, from Sanua to Blunt, Box 54, Blunt Collection, West Sussex Record Office, Chichester.

78“An Arabic Punch,” The Saturday Review, 26 July 1879, 112; “Abou Naddarah,” The Academy, 30 August 1879, 158.

${ }^{79}$ Ninet, "Origin of the National Party in Egypt," 127; and John Ninet, Au Pays des Khédives: Plaquettes Égyptiennes (Genève: Imprimerie Schira, 1890), 32.

${ }^{80}$ Shmuel Moreh, "New Light on Ya'qūb Sanua's Life and Editorial Work through His Paris Archive," in Writer, Culture, Text: Studies in Modern Arabic Literature, ed. Ami Elad (Fredericton: York Press, 1993), 101-15, esp. 102.

${ }^{81}$ Filib di Tarrazi (Philip de Tarrazi), Ta'rikh al-Sihafa al- 'Arabiyya, 4 parts in 2 vols. (Beirut: al-Matba'a al-Adabiyya, 1913, 1914, 1933), vol. 1, part 2, 282-86. In the entry Jarā’id Abī Nazzāra, Tarrazi uses Ya'qūb Șanū' (Jams Sānuwā) al-ma' rüf bi-Ab̄̄ Nazzāra, vol. 1, part 2, 254. Sanua was in contact with Tarrazi in early 1911 about his biographical entry in this book. Tarrazi's letter and Sanua's answer are printed in Moreh, "Ya'qub Sanu': His Religious Identity and Work," Appendix C, 259-262; and Moreh, "New Light on Ya'qub Sanua's Life," 104-105.

${ }^{82}$ In Arabic script, 'Abduh calls him Ya $q u \bar{u} b$ bin Șan̄̄̄', for instance, Abu Nazzara, 17; Najm uses Ya $q u \bar{b} b$ Sannū in al-Masrahiyya, 77; Luqa prefers Yac qūb Sanūac in Arabic (and "James Sanua" in French, in Anouar Louca, Voyageurs et écrivains égyptiens en France au XIXe siècle [Paris: Didier, 1970], 153-78); 'Anus uses $Y a^{`} q u \bar{u} b$ S $a n \bar{u}^{`}$. In English, Gendzier calls him "Ya'qub Sanu'," Badawi, Moosa, and Levy use the fully

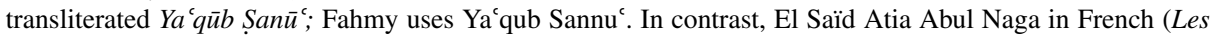
sources françaises du théâtre égyptien [Algiers: Société Nationale d'Edition et de Diffusion, 1972], 75-107) and Sadgrove and Ettmüller in English mention him only as James Sanua.

${ }^{83}$ Ya'qub Sanu', Mulyir Misr wa-ma Yuqasihi (Beirut: al-Matba'a al-Adabiyya, 1912).

${ }^{84}$ This was part of his signature in Abu Naddara Zarqa', 25 March 1878, 4.

${ }^{85}$ Le Cheikh J. Sanua Abou Naddara Chaër-el-Mulk, "Ma vie en vers et mon théâtre en prose" (a lecture held in 1902, published in 1912), republished in part as appendix 2, in Sadgrove, The Egyptian Theatre, 172-85, esp. 184. 


\section{Adam Mestyan}

${ }^{86}$ Moosa asserts that Sanua came perhaps the closest to this claim in his play Mulyir Misr. Moosa, "Ya'qub
Sanu," 404, n. 5.
${ }^{87}$ Sanua, "Ma vie," in Sadgrove, The Egyptian Theatre, 173. Khuri-Makdisi, The Eastern Mediterranean, 67, based on Gendzier, The Practical Visions, 31, who gives no source for this information, states that Jamal al-Din al-Afghani advised Sanua on establishing the theater troupe as a means of "promoting radical ideas." Al-Afghani during his first forty-day visit to Cairo in 1869 possibly did not meet Sanua. Nikki R. Keddie, Sayyid Jamal Ad-Din Al-Afghani: A Political Biography (Berkeley, Calif.: University of California Press, 1972), 81. When al-Afghani arrived for the second time in Egypt, in March 1871, he received a monthly salary of 1000 ghurush based on the support of Riyad Pasha; see Amin Sami Pasha, Taqwim al-Nil, 3 parts in 6 vols., the 3rd part is in 3 vols (Cairo: Dar al-Kutub wa-l-Watha'iq al-Qawmiyya, 2003-2004 [1936]), 3rd part, vol. 2, 913; and Keddie, Sayyid Jamal Ad-Din Al-Afghani, 81-82, n. 1. Thus, at least in his first months, it is not probable that al-Afghani was openly against the khedive. Khuri-Makdisi also claims that al-Afghani saw "the establishment of an Egyptian theater as the most effective way of promoting radical ideas," and that his "influence on the development of the theater was continued by two of his most active disciples, Salim Naqqash and Adib Ishaq" (The Eastern Mediterranean, 198, n. 36). Exactly the contrary occured: Naqqash and Ishaq arrived in Egypt in 1876 as theater artists, but due to the influence of al-Afghani both left the theater for journalism, just as Sanua did. There is no evidence so far that al-Afghani had any influence on the origins of Sanua's theater.

${ }^{88}$ Sanua, "Ma vie," in Sadgrove, The Egyptian Theatre, 173. If "mes élèves" refers to his official job, then the students should be from the Muhandiskhane, L'École Polytechnique in Cairo, where he was a teacher. Moosa, "Ya'qub Sanu'," 405. In Mulyir Misr the actors have mostly Christian Arab or foreign names (Mitri, Habib, Istifan, Ilyas, Butrus, Matilda, Liza) with the exception of 'Abd al-Haliq. Perhaps some of them were street entertainers. Theater historians have made attempts to identify Sanua's theater as an example of Egyptian street entertainment. Most recently, al-Musaylihi, in Su'ali, 57-60, argues that the actors and Sanua were awlād rābiya.

${ }^{89}$ Sanua, L'arabo anziano, 3-4. Sanua's relation to Morpurgo is obscure.

${ }^{90}$ Gendzier mentions two additional early Italian works of Sanua: Amore e disincanno (Cairo, 1865; perhaps Amore e disinganno); and La musa egizia di James Sanua (Cairo, 1873). Gendzier, The Practical Visions, 143. I could not locate these books.

${ }^{91}$ For example, see the anonymous poem "La notte e il giorno - imitazione dell' arabo moderno," Lo Spettatore Egiziano, 13 October 1855, 4.

${ }^{92}$ Sanua, L'arabo anziano, 35-36, 41-42.

${ }^{93}$ Landau claims that Sanua wrote Italian plays before Arabic ones; Sadgrove maintains the opposite. Sadgrove, The Egyptian Theatre, 124, n. 121. L'Arabo anziano proves that Sanua had written dialogues in Italian before 1870 .

${ }^{94}$ Felix Konrad, Der Hof der Khediven-Herrscherhaushalt, Hofgesellschaft und Hofhaltung, 1840-1880 (Würzburg: Ergon Verlag, 2008), 125-27, and the table on 220.

${ }^{95}$ Sanua, "Ma vie," in Sadgrove, The Egyptian Theatre, 174.

${ }^{96}$ Letter dated 27 May 1871 and letter dated 2 June 1871, both from Riaz to Barillet, Carton 62, 'Ahd Isma'il (old system), DWQ. The final inauguration of the Garden took place in 1872. Luisa Limido, L'art des jardins sous le Second Empire: Jean-Pierre Barillet-Deschamps (1824-1873) (Seyssel: Champs Vallon, 2002), 209.

${ }^{97}$ Letter dated 3 April 1871, from Levasseur, Carton 62, 'Ahd Isma'il (old system), DWQ.

${ }^{98}$ Draneht left for Milan on 29 April 1871 and arrived back in Cairo around 10 October. Letter dated 28 April 1871, Draneht to Mariette, and letter dated 12 October 1871, Draneht to Mariette, cited in Busch, Verdi's Aida, 154, 236.

${ }^{99}$ Letters dated 31 May 1871, Rosenboom to Grand, and 1 June 1871, Grand to Riaz Pasha, Carton 80, 'Ahd Isma'il (old system), DWQ.

${ }^{100}$ It is impossible to fully reconstruct the repertoire of the Arabic troupe even in its short one-year existence. It certainly performed comedies by Sanua, a play entitled al-Jawharji by a young Egyptian, Layla by 'Abd al-Fattah al-Misri, and probably al-Bakhil by Marun Naqqash. (Arzat Lubnan, which contained Naqqash's al-Bakhil, was available in 1870 in Cairo.) It has been often suggested that some of Muhammad 'Uthman Jalal's translations were also performed but nothing confirms this assumption. Bardenstein, Translation and Transformation, 146. 
${ }^{101}$ Benedict Anderson, Imagined Communities: Reflections on the Origins and Spread of Nationalism, rev. ed. (London: Verso Books, 2006), 30, 198.

102 ' Abd al-Fattah al-Misri, Lu'bat Layla, 33.

${ }^{103}$ Ibid., 44.

${ }^{104}$ Ibid., 4.

${ }^{105}$ This is similar to the number given by 'Abd al-Fattah, who wrote that his friend composed "more than twelve plays." 'Abd al-Fattah al-Misri, Lu'bat Layla, 3; Sadgrove, "Leyla-The First Egyptian Tragedy," 164. An often mentioned lost play is Patrie et Liberté or al-Watan wa-l-Hurriyya (for instance, Moosa, "Ya'qub Sanu'," 408; and Moreh and Sadgrove, Jewish Contributions, 23) but so far nothing affirms its existence or performance. The play Mulyir Misr (1912) must be excluded from the performed works in 1871-72. Badawi, "The Father of the Modern Egyptian Theater," 143; Sadgrove, The Egyptian Theatre, 113; Levy, "Jewish Writers," 161. Because of the absence of publication, it is not certain that all of Sanua's works in manuscript were performed and vice versa. The printed works include Mulyir Misr and six comedies with one short dialogue (manuscripts discovered by Luqa, published by Najm, 1963). A number of theatrical texts appeared in Sanua's various journals; Najwa Ibrahim 'Anus collected these in Ya'qub Sanu', al-Lu'bat al-Tiyatriyya (Cairo: al-Hay’a al-Misriyya al-'Amma li-l-Kitab, 1987); see Ettmüller, The Construct, 101.

${ }^{106}$ Sadgrove, The Egyptian Theatre, 114, repeats Moosa, "Ya'qub Sanu'," 430.

${ }^{107} \mathrm{Al}$-Sadaqa, in Najm, Ya $q u b$ Sannuc, 128.

${ }^{108}$ Al-Amira al-Iskandaraniyya, in Najm, Ya 'qub Sannu`, 154, 167.

${ }^{109}$ Moreh and Sadgrove, Jewish Contributions, 22.

${ }^{110}$ Moosa, "Ya'qub Sanu'," 418; Fahmy, Ordinary Egyptians, 46.

${ }^{111}$ Wadi al-Nil, quoted in al-Jawa'ib, 27 August 1871, 3. In Sadgrove's translation (The Egyptian Theatre, 98) the difference between dārija and adabiyya is the difference between colloquial and literary Arabic. I slightly modified the translation.

${ }^{112}$ For example, Moosa, "Ya'qub Sanu'," 406; and Fahmy, Ordinary Egyptians, 46.

${ }^{113}$ Sadgrove, The Egyptian Theatre, 111. He bases this explanation on Jerrold's report about the promised financial support and on Mulyir Misr, in which the actors constantly ask for payment. Louis Awad hypothesized that Khedive Ismail denied financial aid because of Sanua's support of his uncle Abdülhalim. Louis Awad, The Literature of Ideas in Egypt, Part 1 (Atlanta, Ga.: Scholars Press, 1986), 71. Although after 1878 Sanua indeed favored Abdülhalim, there is no evidence for this in those early years.

${ }^{114}$ Abu Nazzara Zarqa, 1 July 1879, 2.

${ }^{115}$ Sanua, "Ma vie," in Sadgrove, The Egyptian Theatre, 178.

${ }^{116}$ Sadgrove, The Egyptian Theatre, 109.

${ }^{117}$ The Levant Times and Shipping Gazette, 26 June 1872, 2.

${ }^{118}$ Sadgrove, The Egyptian Theatre, 137-38.

${ }^{119}$ Ettmüller, The Construct, 86.

${ }^{120}$ Abu Nazzara Zarqa, 1 July 1879, 2.

${ }^{121}$ 'Abd al-Fattah Nadim, ed., Sulafat al-Nadim fi al-Muntakhabat al-Sayyid 'Abd Allah al-Nadim, 2 vols. (Cairo: Matba'a Hindiyya, 1914), 1:37.

${ }^{122}$ William Weaver, Verdi: A Documentary Study (London: Thames and Hudson, 1977), 225. 